DOI: $10.4274 /$ mjima.2018.10

Mediterr J Infect Microb Antimicrob 2018;7:10

Erişim: http://dx.doi.org/10.4274/mjima.2018.10

\title{
Our Great Loss - The 10-year anniversary of the passing of our Founding General Secretary, Mustafa Aydın ÇEVIK
}

\author{
Çok Eksiğiz-Ölümünün 10. Yılında Kurucu Genel Sekreterimiz \\ Mustafa Aydın ÇEVIK \\ Dilek ARMAN* \\ Medical Park Bahçelievler Hospital, Infectious Diseases and Clinical Microbiology, İstanbul, Turkey
}

\section{Keywords: Editorial, infectious diseases \\ Anahtar Kelimeler: Editöryal, enfeksiyon hastalıkları}

Ten years have passed... We lost not just a colleague... Our friend, our unifying force, our voice of reason, vanished so suddenly... Virtuous, sensitive, always sincere in his relations, hardworking and truth-seeking, one who inspired those around him to be grateful of his presence, and in his absence, we are incomplete.

I first met Mustafa Aydın ÇEViK in 1998-1999 and had the chance to become better acquainted with him while preparing the Hospital Infection Training Program (Hastane Infeksiyonları Eğitim Programı-HiEP-2000) book, and I recognized his humanistic and just nature in the way he treated everyone and every idea equally.

In later collaborations, I observed that he had no nepotist leanings, but instead valued effort and merit, which could also be understood from the team he built around himself. With Dr. Şebnem ERDiNÇ (now Associate Professor) and Dr. Nurcan BAYKAM (now Professor) and as one who knows how to succeed at the helm, they revived the Refik SAYDAM Institute of Health, which had been considered stagnant for some time, and attained international accreditation of the units. One of our young colleagues says, "He introduced me to topics like vaccine quality control, biosecurity, GMP (good manufacturing practices), and quality management systems." With his great vision, our dear Mustafa was a guiding light not only for young people, but for many of us.

The motivation inspired by Mustafa Aydın ÇEVIK was a key factor in the creation of a large number of scientific works bearing my name published by the Bilimsel Tıp Publishing House, which he founded. Besides the respect shown by every employee of the Publishing House, the affection I saw in their eyes when they looked at Mustafa were like myriad proofs of these many traits. All of the staff at the publishing house were well chosen, but Özlem ÖZTÜRK in particular was Mustafa's gift to the community. Mustafa would not drink alcohol containing beverages himself, but he would take us out "drinking" after a busy work day. Can anyone who shared the atmosphere of tolerance and openmindedness of those busy working days not miss them?

I worked even more closely with Mustafa in 2005-2006, during the establishment of the Infectious Diseases and Clinical Microbiology Specialty Society of Turkey (TÜRKIYEEKMUD).

His observant, empathic approach, rapid adaptation to changing conditions, his friend/leader qualities and his unifier/peacekeeper role were all crucial catalysts in the society's foundation. Despite the necessity of EKMUD, I am not sure we could have taken such a strong step without both Mustafa's wholehearted efforts and his support. Mustafa was like a brother to all of the administrative board members, but as the Founding General Secretary, he was the driving force behind many actions and decisions. His bureaucratic experience and his ability to judge character gave us all a sense of security. All of us now reading this journal and benefiting from the opportunities EKMUD provides owe a great debt to Mustafa. 
Before he became a parliamentary candidate, our society invested in its executive center through our beloved Mustafa's determination and tireless efforts. We later realized that this aimed to separate himself from the society. In order to avoid harming the society for which he laid the foundation and having it labeled as politically biased due to his parliamentary candidacy, it was with great regret that dear Mustafa submitted his resignation from his positions in the General Secretariat and the Administrative Board. It was a decision based on principle, and for any other of us in a similar situation, the board would have unhesitatingly and unanimously accepted the resignation. But we could not bear to lose our beloved Mustafa, we simply felt he should not leave. After the election process was over, we continued to work together with the same enthusiasm and energy. We were so focused on our work that when he complained of a stomach ache at our meeting three days earlier, we never suspected--so many doctors, and it never came to any of our minds to say, "You should see a cardiologist..." As we left that meeting, I thanked him for assisting a valuable colleague of mine when I asked him years ago, and it was an absolution. We were to meet at the congress three days later, but we received the terrible news. We could not imagine it, but approximately 10 months later, we bid farewell to our General Secretary, our friend, our voice of reason, our unifying force.

I consider our beloved Ibrahim ÇEVIK, who shouldered all of his brother's responsibilities following Mustafa's passing, as the inheritance he left to us. Bilimsel Bilişim, which Ibrahim sowed and grew, and was enriched by Mustafa's legacy, has become a scientific media that rivals examples elsewhere in the world and serves as an important tool for our junior colleagues to develop and stay up-to-date.

Amid all of these efforts and attempts to leave his mark, the expression in his eyes when Mustafa looked at his beloved sons Numan IIlteriş and spoke of Ertuğrul Emre is still vivid in my mind. I consider all of them to be entrusted to me by our beloved Mustafa, who I witnessed to be a wonderful person, big brother, and father, and I am sure was also a wonderful husband and son.

Can a person never get angry? I was often at odds with Mustafa while we shared a working environment, and we even argued-but I never saw him get angry. If only you had not suppressed your feelings so much, my friend... If only you had instead lived to see Numan graduate from medical school and start his residency, and become a young man, to see Hatice Umay come into the world and grow into a beautiful young girl, to see the successes of your dear brothers, Osman and Ibrahim. You would have seen the growth of EKMUD and MJIMA (Mediterranean Journal of Infection, Microbes and Antimicrobials), which we sowed together.

Our dear Mustafa Aydın ÇEVIK was a friend and confidante to many of our colleagues who hold very different world views. We still feel your loss, we are still incomplete in your absence.

We remember and miss him dearly.

May him rest in peace...

Acknowledgement: During the preparation of this memorial, I asked for the contribution of different views of our dear friend Mustafa Aydın ÇEViK. I would like to thank my dear friends Assoc. Prof. Şebnem ERDINÇ, MD and Prof. Sercan ULUSOY, MD for their support, and the editors of MJIMA for giving me this opportunity.

*Dilek Arman is the EKMUD Founding President and the Past and Founding Editor in Chief of MJIMA. 